\title{
The Development Trend of Electronic Money and Its Influence on Currency Liquidity
}

\author{
Yaxian Lu \\ International Business School \\ Yunnan University of Finance and Economics \\ Kunming, China \\ 980312863@qq.com
}

\author{
Zhaowen $\mathrm{Su}^{*}$ \\ International Business School \\ Yunnan University of Finance and Economics \\ Kunming, China \\ 980312863@qq.com
}

\begin{abstract}
With the development of Internet and mobile communication, it has become an indispensable part of people's daily life, mobile payment and online payment has become an significant way of payment. The goal of this paper is to study the emergence and development of electronic money and to prove that its development not only changed the form of money, but also changed the supply structure of money, which had a significant impact on monetary liquidity. The test of the correlation between electronic money and monetary liquidity proves that electronic money has a distinct substitution effect on the currency with strong liquidity, but this substitution is not a simple form of substitution.
\end{abstract} supply

Keywords-electronic money; currency liquidity; money

\section{INTRODUCTION}

This paper uses the qualitative analysis method, the data comparison analysis method, the literature review method to carry on the analysis.Combining the theoretical research with the data analysis, analyzes the development and influence of the electronic money from different angles, and reflects the relationship between the electronic money and the money supply.Around the electronic money on the money supply and monetary liquidity of the two perspectives, first of all, according to the relevant literature to review and analysis, respectively, to discuss the role of electronic currency on the circulation of cash, the role of money multiplier and money supply, and then use China's macroeconomic and financial data, combined with charts for analysis, finally draw conclusions.

\section{LITERATURE REVIEW}

\section{A. On the Definition and Development of Electronic Money}

In the foreign study, the Bank for International Settlements has also made a comprehensive discussion on the basic definition and attributes of electronic money, the influence of electronic money on money supply and demand, money multiplier and currency circulation rate and electronic money security.Among them, BIS (2004) discussed the relationship between electronic money and money multiplier and currency circulation rate in detail. On the basis of a detailed definition of the concept of electronic money, BIS (2007) [2] found that the impact of electronic money on money multiplier and currency circulation is

\footnotetext{
*Corresponding author
}

becoming increasingly significant and has different effects on different levels of currency. BIS series of papers on the theory of more rigorous, for the late domestic and foreign research has played a very important guiding role.

\section{B. The Influence of Electronic Money on Monetary Fluctuation}

In electronic money influence on monetary liquidity, challenge of electronic currency to traditional monetary theory has aroused widespread concern of governments, central banks and academia. From the existing literature, literature in effect of electronic money on currency liquidity is a relative lack, and theoretical circle has not yet reached consensus.In order to explore the reasons for the long-term decline of money liquidity, the domestic academic circles have carried on the extensive research,and achieved some valuable achievements.Yin hang(2014) [7] studied the monetary nature of the electronic currency,the emphasis is on the premise of the theory of credit,on the basis of the definition of electronic money as a kind of private credit currency, the study of the influence on the credit system is studied.

\section{Electronic Money Affects Money Supply}

Jiang Shaohua (2013) [4] used the relevant data of 19782012 to study the influence of electronic money on the velocity of money, the money multiplier and the cash amount in the circulation. It was concluded that the electronic money had an influence on the three.Hu Zanyong (2015) [3] from the perspective of narrow money to discuss and discuss the development of narrow sense of electronic money is one of the factors to determine the demand for money. According to the actual data show that the trend of demand for money was inverted V-shaped first rise and then downward trend, it also brought the endogenous nature of the money supply continues to increase.Yang Gefan (2014) [6], when the empirical test is conducted, the electronic money data of the third party payment institution is included in the electronic money data, which fills the gap of the electronic money data in the domestic study. Wang Liang, $\mathrm{Wu}$ Bangyuan (2013) [4] found that electronic money by changing the money supply demand structure and the speed of currency circulation has an impact on inflation. They have concluded that the effect of Chinese electronic money on inflation is significant, and the decline in the current currency circulation rate reduces the inflation rate, but the 
TABLE I. Data on Electronic Money And CuRrency Liquidity (1998-20012)

\begin{tabular}{|c|c|c|c|c|c|c|c|}
\hline Years & $\begin{array}{c}\text { Currency } \\
\text { liquidity }\end{array}$ & $\begin{array}{c}\text { Cash } \\
\text { holding rate }\end{array}$ & $\begin{array}{c}\text { Currency } \\
\text { ratio }\end{array}$ & Years & $\begin{array}{c}\text { Currency } \\
\text { liquidity }\end{array}$ & $\begin{array}{c}\text { Cash } \\
\text { holding rate }\end{array}$ & $\begin{array}{c}\text { Currency } \\
\text { ratio }\end{array}$ \\
\hline 1998 & 0.37 & 0.4 & 0.29 & 2006 & 0.36 & 0.27 & 0.21 \\
\hline 1999 & 0.38 & 0.42 & 0.29 & 2007 & 0.38 & 0.25 & 0.2 \\
\hline 2000 & 0.39 & 0.38 & 0.28 & 2008 & 0.34 & 0.26 & 0.21 \\
\hline 2001 & 0.38 & 0.36 & 0.26 & 2009 & 0.36 & 0.21 & 0.2 \\
\hline 2002 & 0.38 & 0.32 & 0.24 & 2010 & 0.37 & 0.21 \\
\hline 2003 & 0.38 & 0.31 & 0.23 & 2011 & 0.34 & 0.31 & 0.18 \\
\hline 2004 & 0.38 & 0.29 & 0.22 & 2012 & 0.31 & 0.21 \\
\hline 2005 & 0.36 & 0.29 & 0.22 & & & & 0.18 \\
\hline
\end{tabular}

rise of the future currency circulation rate will accelerate the formation of inflation.

In summary, the domestic and foreign issues related to electronic money affect the money multiplier, the speed of money circulation, money supply, monetary policy and other aspects of a large number of analysis and research, and achieved some success. However, in previous studies, there have been few studies on the effects of electronic money on monetary liquidity, although some scholars have mentioned their problems in the study of electronic money-related issues, but did not carry out specialized analysis and research.To this end, this paper in the study of electronic money on the basis of scholars to explore the development of electronic money and its impact on monetary liquidity.Although the emergence of electronic money is not short, but because of the level of application of science and technology and the development of the network economy, electronic money is in constant innovation, the Chinese scholars have not much research.Therefore, this aspect provides the research space for this topic, and on the other hand, it also provides a reference for the development model of China's electronic money.

\section{DATA DESCRIPTION}

\section{A. Formula Analysis}

With reference to the International Monetary Fund's framework for money supply statistics, according to the different liquidity, China's monetary hierarchy is divided as follows:

\section{$\mathrm{M} 0=$ Cash in circulation}

\section{$\mathrm{M} 1=\mathrm{M} 0+$ Demand deposits}

$\mathrm{M} 2=\mathrm{M} 1+$ Time deposit+Savings deposits + Other deposits + Securities company customer margin

In general, countries in accordance with the order of liquidity from high to low, the money supply is divided into M0, M1, M2, M3 and so on.Among them, the most
Source: By calculating the relevant data of China Financial Yearbook

common hierarchical division is M0, M1, M2, M3.Although there is a big difference between the various countries in the level of money supply, but the various levels of money in the economy still has some basic characteristics and common meaning.In the real economic statistics, in order to make the currency statistical caliber to adapt to the needs of economic development and changes, need to be adjusted frequently, so as to avoid improper statistical caliber lead to the wrong form of economic development.Because of this, all levels of the currency contains the content is not consistent, but with the new financial payment tools and the development of electronic money to change the original corresponding to the level of the currency, and then more accurately reflect the results of changes in asset liquidity structure, so as to continuously improve the amount of money at all levels of statistics.

\section{B. Data Analysis}

Although the development of electronic money in China started late, but with the rapid development of electronic money, China's monetary liquidity has been declining trend.In this paper, use the data from 1998 to 2012 to illustrate the relevant data. (See Table 1)

As can be seen from Table 1, from 1998 to 2012, China's monetary liquidity declined from $37 \%$ in 1998 to $31 \%$ in 2012, showing a steady decline, and has not yet bottomed out.At the same time, the replacement rate of electronic money is rising rapidly, especially after entering the 21 st century, showing a rising trend.This shows that in the early stages of the development of electronic money, electronic money is mainly replaced by a more liquid currency.

At the same time, cash holdings have been declining, falling from $40 \%$ in 1998 to $21 \%$ in 2012, showing a downward trend in the same direction as monetary liquidity. This shows that the electronic currency in the alternative high liquidity currency, the main alternative is the most liquid cash M0, so that it is converted into bank demand 
deposits, thus keeping the cash holdings declining, so there is a clear positive correlation between monetary liquidity and cash holdings.

\section{A Theoretical Analysis of the Influence of Electronic Money on Money Multiplier}

The traditional money multiplier formula is :

$$
m=\frac{M s}{H}=\frac{C+D}{C+R}=\frac{C / D+1}{C / D+R / D}
$$

Where $\mathrm{C} / \mathrm{D}$ is the currency ratio $\mathrm{k}$ and $\mathrm{R} / \mathrm{D}$ represents the reserve ratio $\mathrm{r}$, so the size of the money multiplier is determined by these ratios.

When taking into account the electronic money, the formula for the money multiplier will change, below we will discuss the situation after the addition of electronic money, set the electronic balance is EM, then the money supply formula will become: $\mathrm{Ms}=\mathrm{C}$ ' $+\mathrm{EM}+\mathrm{D}^{\prime}$. Among them, because the electronic currency may replace part of the cash or deposit, C ', D' denote the cash balance and deposit money China's development of electronic money, the amount of card issuance, network operators to join the amount of acceptance of the terminal layout, the number of transactions and the transaction volume of several specific circumstances, shown in Table II .

- Increases the money multiplier effect, strengthens the endogenous of the money multiplier.

- Electronic money has little effect on China's narrow money multiplier, has a great influence on the broad money multiplier, which further drives China's currency from M1 to M2.

\section{DATA ANALYSIS}

\section{A. An Analysis of the Current Situation of Electronic Money Development}

The eighties of last century, the Chinese bank card industry began to start.With the electronic process of the

TABLE II. Development of China Bank CARd Payment System In 2008 - 2013

\begin{tabular}{|c|c|c|c|c|c|c|}
\hline Years & $\begin{array}{c}\text { Amount of } \\
\text { issuance (Billion) }\end{array}$ & $\begin{array}{r}\text { ATM } \\
\text { (Million) }\end{array}$ & $\begin{array}{l}\text { Networking } \\
\text { business }\end{array}$ & POS machine & $\begin{array}{l}\text { Number of } \\
\text { transactions }\end{array}$ & $\begin{array}{l}\text { Amount of } \\
\text { transaction }\end{array}$ \\
\hline 2008 & 18 & 16.75 & 118.17 & 184.51 & 166.7 & 127.16 \\
\hline 2009 & 20.66 & 21.49 & 156.65 & 240.83 & 196.91 & 165.99 \\
\hline 2010 & 24.15 & 27.1 & 218.3 & 333.4 & 257.57 & 246.76 \\
\hline 2011 & 29.49 & 33.38 & 318.01 & 482.65 & 317.8 & 323.83 \\
\hline 2012 & 35.34 & 41.56 & 483.27 & 711.78 & 389.14 & 346.22 \\
\hline 2013 & 42.14 & 52 & 763.47 & 1063.21 & 475.96 & 423.36 \\
\hline
\end{tabular}

balance after joining the electronic currency.So the money multiplier will become:

$m^{\prime}=\frac{C^{\prime}+E M+D^{\prime}}{C^{\prime}+R^{\prime}}=\frac{C^{\prime} / D^{\prime}+E M / D^{\prime}+1}{C^{\prime} / D^{\prime}+R^{\prime} / D^{\prime}}$

Firstly, assume that the electronic currency replaces the cash.When the electronic money replaces part of the cash, the sum of the cash $\mathrm{C}$ 'and the electronic money EM in circulation is equal to the previous cash $\mathrm{C}$, and the deposit is invariant, thereby obtaining $\mathrm{C}=\mathrm{C}^{\prime}+\mathrm{EM}, \mathrm{D}=\mathrm{D}^{\prime}$. At this time $\mathrm{C}^{\prime} / \mathrm{D}^{\prime}$ is smaller than the previous $\mathrm{C} / \mathrm{D}$, and $\mathrm{C}^{\prime} / \mathrm{D}^{\prime}+$ $\mathrm{EM} / \mathrm{D}$ 'is equal to $\mathrm{C} / \mathrm{D}$, and the electronic currency alternative part of the cash does not affect the deposit reserve, so $\mathrm{R}^{\prime}$ / $\mathrm{D}$ ' equal to $\mathrm{R} / \mathrm{D}$. Thus, the money multiplier $\mathrm{m}$ can be pushed out.

Through the formula derivation and analysis are summarized as follows:

- Electronic money affects the money multiplier by factors such as time deposit ratio, excess reserve ratio and currency ratio. And the development of electronic bank card system continues to advance, the bank card in people's daily life related to basic necessities, learning, entertainment and other aspects of payment settlement, play an increasingly important role.The liquidity and acceptability of bank card electronic money are increasing, and the substitution effect of cash payment and settlement function is also increasing day by day.

China's development of electronic money, the amount of card issuance, network operators to join the amount of acceptance of the terminal layout, the number of transactions and the transaction volume of several specific circumstances, shown in Table II

Compared to the data from 2008 to 2013 we can see that the bank card inter-bank payment system networking business, networking POS machines and bank cards pay the number of cross-year growth rate is accelerating trend, the overall amount of transactions is also the trend of accelerating year by year, only in $2011-2012$ slowdown.It 
can be seen that China's bank card industry has gradually become mature, the back-end environment to gradually optimize and improve, into a virtuous circle.

\section{B. The status of Online Payment Development}

Online payment is from 2000 to gradually grow up, but with the Internet in 2000 the bubble burst, until 2002, the basic development of online payment in a stagnant state. After the "SARS" in 2003, the number of online shopping companies began to develop rapidly, commercial banks, Internet banking began to quickly promote.Third-party payment platform began to rise, China's online payment began to enter the rapid growth of the channel, the online market scale from 80 billion yuan in 2007 soared to 320 billion yuan in 2008. As of the end of 2014, according to the report of the People's Bank of China, China's online payment inter-bank clearing system handled a total of 1.639 billion business, the total amount of 17.79 trillion yuan, dealing with 452.8 million business, the amount of 49.142 billion yuan.Figure 5 shows the changes in the scale and growth rate of online payment market in China from 2005 to 2014.

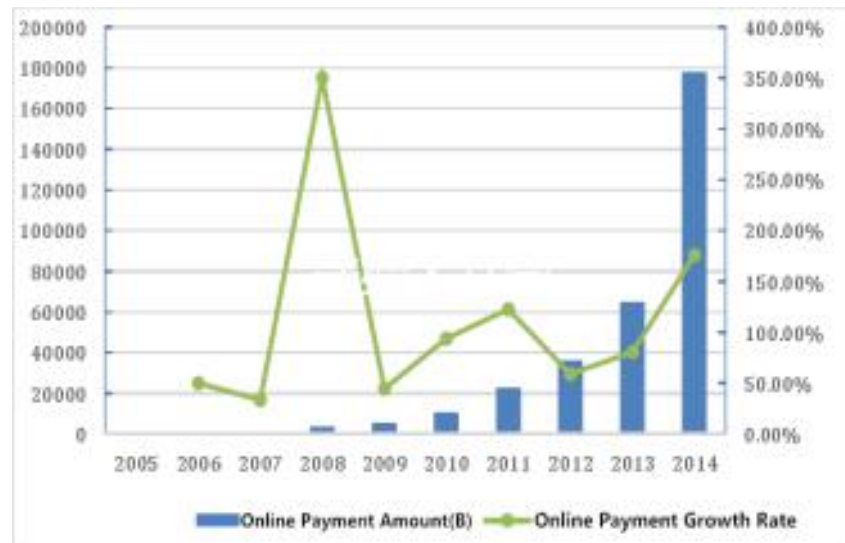

Fig. 1. Online payment market size and growth rate trends from 20052014

Through the electronic money-related data to sort out and analyze the conclusion, as the Internet technology advances, many electronic money issuers use the network to create and distribute electronic money, so many electronic money is issued by non-financial institutions.In view of this, the emergence of electronic money to increase the pressure on financial institutions and financial institutions and nonfinancial institutions between the competition.Electronic money can be high-speed circulation, simplifying the transition between different financial assets, reducing the cost of change, which not only to the central bank to manage monetary liquidity caused interference, but also become one of the factors of central bank to adjust monetary policy and money supply.

\section{C. he Development of Typical Electronic Money - Bitcoin}

Bitcoin is a typical electronic virtual currency, it was born in the global financial crisis after the second year, is 2009. Most of its application lies in the Internet financial investment, rather than online virtual goods trading, which is other electronic virtual currency does not do.The emergence of Bitcoin subversion of the original concept of electronic virtual currency, the monetary and financial system caused a certain impact.

Bitcoin was first used as money in May 2010.A Florida programmer uses 10,000 bits of coins to buy two pizza, which is the first time that a record has been used to trade Bitcoin as a real-life currency. At present, the mainstream website began to support Bitcoat payment, cloud storage services Mega founder Kim Dotcom announced that began to support Bitcoal settlement, the user can use the bit to buy Mega paid service on February 17, 2013.On the same day, social news site Reddit announced that users can use Bitcoin to pay. A survey shows that thousands of businesses around the world that accept Bitcoin as currency settlement. At the same time, the wireless network payment system has begun to try, Bitcoin Wireless's formal operation makes hundreds of countries Wifi network support Bitcoin payment. These facts prove that Bitcoin may enter the physical financial system.

As a new product after the financial crisis, Bitcoin in the rapid development of contradictions.Although the bitcover boom has receded, but the power of Chinese investors still can not be ignored. As China becomes a mining center for Bitcoin, China's Bitcoin market will continue to expand, and countries around the world will gradually increase the acceptance of Bitcoin. The outlook for the bitcover market is still very good.

\section{CONCLUSION AND SUGGESTION}

\section{A. Conclusions}

1) The substitution effect of electronic money on cash in circulation

This paper argues that with the change of information technology, electronic payment began to be gradually selected by the public, this led to the gradual replacement of cash, in the money supply, the proportion of cash also began to show a downward trend.But found from the actual research results, at present, the impact of China's electronic currency on cash is a "growth substitution".From the macro data found that in recent years the absolute number of cash in circulation is still growing, but the growth rate is showing a decreasing trend, and the absolute number also began to reduce the trend.

\footnotetext{
2) Electronic money has changed the structure of money supply

This paper argues that the cash substitution effect and cash conversion effect caused by electronic money will change the scale of China's base currency firstly. And the structure of different levels of money supply will change, the proportion of cash in circulation will decline, the proportion of reserves will rise.With the development of electronic money, there will be loans to create deposits, so that the central bank will increase the supply of base money.
} 
3) The effect of electronic money on money circulation speed

The impact of electronic money on the velocity of money is mainly reflected in the development of electronic money will make cash flow faster, theoretically, the speed of circulation of money at all levels should be accelerated.But the electronic currency has the effect of currency substitution and transformation effect, the substitution effect will make the narrow money circulation rate decline, the transformation effect will make the generalized currency circulation speed decline, narrow money circulation rate is relatively rising.

\section{B. Suggestions}

For now, the behavior of electronic money issuance and circulation has an important influence on the policy choice of the central bank, these made a few suggestions:

\section{located}

1) The main body of regulation should be clearly

This paper argues that since third parties pay for business in multiple areas, it will become a financial trend, this requires financial regulators to collaborate in the management process to improve regulatory efficiency.

2) Educate consumers on financial knowledge and risk prevention knowledge

Everything has a contradictory two aspects, the development of electronic money is no exception, it gives consumers a quick and easy way to pay for the life experience while also bringing potential risks.Diversified payment environment will make the account facing the risk of being stolen, through the popularization of risk knowledge, enhance their risk prevention ability, so that the electronic money market stable and orderly development.
3) The central bank changes its role in the development of electronic money

The central bank should change its role.The rapid development of electronic money seriously challenges the status of the central bank, the central bank to comply with the electronic currency to replace the trend of currency or coins, adjust their functions, adjust their own functions, to enhance the control of electronic money issuance, make decisions and strict control.At the same time, the central bank should speed up the process of issuing electronic money in the name of the state, to promote the historical evolution of currency digitization.Because it will be related to the central bank's control of the base currency, affecting its control of money supply, and may even affect the realization of monetary policy objectives.

\section{REFERENCES}

[1] BIS, "Survey of Developments in Electronic Money and Internet and Mobile Payments," BIS Working Paper, 2004.

[2] BIS, "The BIS Statistics on Payments and Settlements," BIS Quarterly Review, p. 41, June 2007.

[3] Z.Y. Hu, "An Empirical Study on the Effects of Electronic Money on Short - term Interest Rates: Based on the Perspective of Narrowed Electronic Money," Journal of Shanghai Institute of Finance, 2015, pp. 19-28.

[4] S.H. Jiang, "Research on the Influence of Electronic Payment Development on Central Bank 's Monetary Policy," Chinese Academy of Social Sciences doctoral thesis, 2013.

[5] L. Wang, "2013.Inflation Effect of Electronic Money: An Empirical Analysis Based on 2003 - 2011 Quarterly Data," Financial Science, 2013.

[6] G.F. Yang, "A Study on the Mechanism of the Influence of Electronic Money on Money Supply and Currency Multiplier - A Three-level Creation System Containing Third Party Payment Institutions," Shanghai Finance, 2014, pp. 47-54.

[7] H. Yin, "The Influence of Electronic Currency of Credit Monetary System-Based on Free Competition in the Market," Journal of Financial Research, 2014. 